\title{
PENINGKATAN KEMAMPUAN KOMUNIKASI SISWA KELAS II SD MELALUI METODE DONGENG
}

\author{
Pupung Puspa Ardini \\ Pendidikan Guru Pendidikan Anak Usia Dini \\ Universitas Negeri Gorontalo
}

\begin{abstract}
ABSTRAK
Penelitian ini bertujuan untuk dapat meningkatkan kemampuan komunikasi siswa kelas II Sekolah dasar melalui pelaksanaan metode dongeng. Melalui dongeng siswa akan banyak menyimak perbendaharaan kata baru dan juga berinteraksi dengan pendongeng sehingga kemampuan berkomunikasi siswa dapat meningkat. Subjek penelitian adalah siswa kelas II SDIT AlHusna Bekasi Utara, Jawa Barat. Metode Penelitian yang digunakan dalam penelitian ini adalah Penelitian Tindakan kelas atau Classroom Action Research. Terdiri dari 2 siklus. Dari hasil tindakan dari siklus pertama (1) dan kedua (2) terjadi peningkatan. Peningkatan tersebut terlihat dari perbedaan rata-rata skor aktivitas anak pada siklus 1 dan siklus 2. Adapun peningkatan tersebut pada siklus 1 memperoleh skor 63 pada kriteria cukup aktif dan siklus kedua skornya meningkat menjadi 97 termasuk kriteria sangat aktif selain itu harapan lain adalah program kegiatan berdongeng dapat diterapkan dalam kegiatan pembelajaran untuk siswa kelas II SD dalam meningkatkan kemampuan komunikasi siswa.
\end{abstract}

Kata Kunci : Kemampuan komunikasi, kelas II SD, metode dongeng

\section{A.PENDAHULUAN}

Indonesia adalah negara kesatuan yang terdiri dari beribu-ribu pulau. Dari ribuan pulau tersebut tersebar berbagai macam suku bangsa yang memiliki beragam bahasa dan kebudayaan. Bahasa merupakan simbol lisan yang digunakan oleh masyarakat untuk berkomunikasi dan berinteraksi dengan sesama. Bahasa tersebut digunakan berdasarkan pada kesepakatan bersama dalam masyarakat dan juga berlandaskan pada budaya yang dimiliki bersama (Dardjowojiyo , 2010 : 16).
Kegiatan pengenalan bahasa yang paling sederhana adalah melalui komunikasi. Proses ini dilakukan dengan menggunakan Bahasa Indonesia yang baik dan sopan (Peraturan Menteri Pendidikan Nasional nomor 23 tahun 2006). Melalui komunikasi sederhana tersebut pendidik dapat mengajak siswa mencintai bahasa Indonesia sejak dini dimulai dari dalam lingkungan keluarga, sebagai lembaga pendidikan pertama dan utama. Kemudian ketika anak sudah mulai memasuki usia sekolah, gerakan mencintai bahasa Indonesia dilakukan di dalam pembelajaran. 
PEDAGOGIKA

Jurnal IImu Pendidikan

Volume 9 (Nomor 2) 2018

Komunikasi mendukung perkembangan perbendaharaan kata pada anak usia dini. Melalui komunikasi terjadi proses pertukaran informasi, pemikiran atau ide-ide yang kemudian direspon kembali oleh si lawan bicara. Hal ini terkait dengan teori pengkondisian operan Skinner dalam Crain. Teori ini mengemukakan bahwa "stimulus mendahului respon dan otomatis memunculkannya" (Crain, 2007 : 277) Ketika seseorang memberikan informasi atau saran atau ide sebagai stimulus kepada orang lain kemudian secara otomatis pihak yang di ajak bicara ini merespon percakapan tersebut. Dengan demikian secara otomatis anak berlatih berbicara dan semakin memperkaya perbendaharaan kata.

Kekayaan perbendaharaan kata ini secara otomatis juga mengembangkan kemampuan bercerita anak usia dini khususnya siswa Kelas II Sekolah Dasar. Hal ini terdapat dalam sebuah penelitian komunikasi. Penelitian tersebut menyebutkan bahwa komunikasi mempengaruhi prestasi siswa secara signifikan. Dengan kata lain semakin sering komunikasi dilakukan maka prestasi siswa semakin baik, karena semakin banyak perbendaharaan kata yang siswa miliki (Jurnal, Nugroho, 2009).
Namun kenyataan di lapangan, masih terdapat 13 siswa dari 22 siswa di Kelas II SDIT AL Husna yang kurang dapat mengemukakan pendapat serta ideide yang dimiliki kepada orang lain dan. Beberapa siswa sulit mengkomunikasikan pendapat dan keinginan kepada lawan bicara seperti guru atau teman sebaya. Sehingga terkadang masih muncul konflik antar teman sebaya karena kesulitan berkemonikasi tersebut (Observasi awal, Agustus 2014).

Hal lain yang dapat dilakukan untuk mengembangkan kemampuan komunikasi adalah melalui dongeng. Ketika anak membaca atau mendengarkan dongeng dan kemudian menceritakan dongeng tersebut kembali, anak akan memperoleh serta mempelajari berbagai kosakata baru. Selain itu, dongeng yang dibaca atau didengar oleh anak, maka kemudian anak akan memvisualisasikan cerita tersebut kedalam imajinasi (Jurnal, Cendana, 2010). Oleh sebab itu dongeng menarik bagi anak, karena cerita dalam dongeng mampu membawa anak kedalam dunia imajinasi. Dengan demikian dongeng dapat menjadi salah satu pendekatan pembelajaran yang menyenangkan bagi anak. Hal ini terkait dengan penyerapan informasi atau materi ke dalam memori anak. Jika informasi 
PEDAGOGIKA

Jurnal IImu Pendidikan

Volume 9 (Nomor 2) 2018

yang disampaikan oleh guru menarik maka anak dapat dengan mudah menerima informasi. Seperti yang dikemukakan oleh Gagne, yaitu stimulasi yang dapat menarik perhatian, maka dengan mudah informasi tersebut terserap dan menetap di alam memori jangka panjang anak atau (Jurnal, Astuti,2011).

Hal ini dikarenakan sikap pesimis dari para guru untuk mengunakan dongeng sebagai salah satu cara melakukan variasi mengajar. Guru sering khawatir materi yang disampaikan dengan mendongeng tidak sesuai dengan materi yang diajarkan.

Hal ini disebabkan karena masih kurangnya pengetahuan yang guru miliki tentang dongeng. Selain itu, pemahaman guru terhadap dongeng juga masih kurang, sehingga ketidaktersediaan media untuk mendongeng juga dijadikan alasan oleh guru untuk tidak menggunakan dongeng sebagai salah satu variasi dalam mengajar (Jurnal, Kusmiadi, 2011).

Penelitian ini bertujuan untuk mengetahui Pelaksanaan metode dongeng dapat meningkatkan kemampuan komunikasi siswa kelas II Sekolah dasar. Oleh sebab itu, peneliti tertarik untuk melakukan penelitian tindakan kelas mengenai peningkatan kemampuan berkomunikasi siswa kelas II Sekolah Dasar melalui metode Dongeng. Hal tersebut berdasarkan beberapa masalah yang telah dibahas sebelumnya dan masih sering terjadi dalam kegiatan belajar mengajar di kelas.

\section{B.KAJIAN TEORI}

\section{Dongeng}

Dongeng adalah cerita khayal baik itu dalam bentuk tertulis maupun oral yang sudah ada sejak dulu. Dongeng di sampaikan secara turun-temurun. Cerita dalam dongeng berkisah tentang kebaikan melawan kejahatan. Kisah dalam dongeng biasanya menceritakan tentang masyarakat, sejarah, fenomena alami dan perjuangan terhadap harapan untuk sebuah perubahan (Huck, Hepler, dan Hickman,1987 ： 254,Priyono， 2006:9, Carr, Lemon dan Cannadine dalam Pranoto,2010:1, Sawyer dan Comer, 1996:89, Einon, 2006 : 172) .

Cara mendongeng dibedakan menjadi dua, yaitu 1) mendongeng tanpa alat peraga, 2) Mendongeng dengan alat peraga. Mendongeng dengan alat adalah dongeng yang dilakukan dengan menggunakan berbagai alat peraga atau properti sebagai penunjang cerita seperti, buku cerita, boneka tangan, dan lain sebagainya. Sedangkan mendongeng tanpa alat tidak menggunakan alat peraga dan pendongeng hanya mengandalkan 
PEDAGOGIKA

Jurnal IImu Pendidikan

Volume 9 (Nomor 2) 2018

ekspresi, mimic wajah, intonasi serta suara-suara yang ditirukan pendongeng mengikuti suara aslinya (Ralibi, 2008:50).

Terdapat beberapa hal yang perlu diperhatikan saat mendongeng diantaranya, yaitu : (1)Cerita harus sesuai dengan tahapan perkembangan anak, (2) Mengandung unsur nilai-nilai pendidikan dan hiburan, (3) usahakan selalu tercipta suasana gembira saat mendongeng, (4) Bahasa harus sederhana, sesuai tingkat pengetahuan anak, (5) Pendongeng menghayati benar isi cerita yang dibawakan dan meresapi seluruh bagian dari cerita yang didongengkan, (6) Selalu mengamati perkembangan reaksi emosi pada diri anak tetap mempertahankan kesan menyenangkan, (7) Kata-kata yang diucapkan harus jelas tidak seperti bergumam, (8) Melibatkan anak-anak secara aktif dalam cerita yang didongengkan, (9) Pendongeng berusaha menjaga kerahasiaan jalan cerita agar anak tetap terpusat pada tiap adegan, 10) Durasi dongeng disesuaikan dengan situasi dan kemampuan anak dalam mendengarkan dongeng (Qudsy dan Nurhidayah, 2010 : 119).

Berdasarkan jenis cerita dongeng diklasifikasikan ke dalam lima macam : (1) legenda, (2) fabel, (3)Sahibul Hikayat, (4) Mite, (5) Cerita rakyat. Legenda adalah dongeng yang berkisah tentang asal mula terjadinya suatu tempat, tradisi, dan lain sebagainya. Sebagai contoh, legenda berdirinya candi prambanan. Fabel adalah cerita tentang binatang dengan sisipan pesan moral. Sebagai contoh, kisah lumbalumba dan hiu mulut lebar. Sahibul Hikayat adalah cerita tentang tokoh dengan tujuan untuk meneladani tokoh yang diceritakan dalam dongeng tersebut, sebagai contoh kisah para sahabat nabi. Mite adalah cerita yang menjelaskan tentang fenomena sosial yang alami atau takdir manusia dan interaksi manusia dengan supranatura, sebagai contoh dongeng tentang Dewi Sri atau Dewi padi. Cerita rakyat adalah cerita yang diceritakan secara turun-temurun dan merupakan sebuah kebudayaan, sebagai contoh kisah bawang merah dan bawang putih (Eliason dan Jenkins, 2008:189).

Berdasarkan ide cerita dongeng dibagi menjadi enam macam, diantaranya : (1) dongeng tradisional, (2) dongeng futuristic atau moderen, (3) dongeng pendidikan, (4) dongeng fabel, (5) dongeng sejarah, (6) dongeng terapi. Dongeng tradisional adalah dongeng dengan ide yang bersumber dari ceritacerita rakyat atau asal-usul terjadinya suatu daerah. Dongeng Futuristik adalah dongeng dengan ide yang bersumber dari 
PEDAGOGIKA

Jurnal IImu Pendidikan

Volume 9 (Nomor 2) 2018

imajinasi tentang masa depan. Dongeng pendidikan adalah dongeng dengan ide yang sengaja dibuat untuk merubah perilaku seseorang. Dongeng fabel adalah dongeng dengan sumber ide dari hewanhewan. Dongeng sejarah adalah dongeng dengan sumber ide yang berasal dari sejarah para tokoh. Terakhir adalah dongeng terapi, yaitu dongeng dengan sumber ide untuk menangani orang-orang yang mengalami trauma terhadap suatu peristiwa (Qudsy dan Nurhidayah, 2010 : 114-115).

Dongeng yang disampaikan harus sesuai dengan usia anak, karena setiap anak memiliki perbedaan tahapan perkembangan di tiap tahapan usia (Eliason dan Jenkins, 2008:189). Dongeng yang sesuai untuk anak usia 7-8 tahun atau siswa Kelas II Sekolah Dasar adalah dongeng- dongeng seperti legenda, cerita rakyat, cerita binatang, fiksi, cerita ilmu pengetahuan, cerita yahg berhubungan dengan hobi-hobi dan minat, serta ceritacerita petualangan. Isi cerita hendaknya berisi tentang contoh-contoh kategori yang beragam termasuk perbedaan budaya, gender, dan etnis. Tema yang terkandung dalam cerita hendaknya mengandung nilainilai penting dan para tokohnya haruslah memiliki karakter yang kuat.
Dasar teori yang berkaitan dengan dongen adalah teori sociocultural. Teori sociocultural adalah sebuah teori yang menegaskan tentang perkembangan dialog kooperatif antara anak dengan pengetahuan dari lingkungan masyarakat. Anak mempelajari kebudayaan seperti cara berpikir dan merubah perilaku melalui interaksi dengan lingkungan masyarakat (Woolfolk, 2007: 39). Teori sociocultural di gagas oleh Lev Semenovich Vygotsky. Menurut Vygotsky dalam woolfolk, belajar merupakan proses yang melibatkan dua element penting. Pertama pada lingkungan sosial (Interpsychological). Kedua pada tingkat individu (Intrapsychological). Dengan kata lain, belajar melalui proses sosial dimana orang-orang berinteraksi dan bernegoisasi (secara verbal) untuk menghasilkan sesuatu, memahami atau memecahkan masalah. Proses ini disebut co-construced yang merupakan proses mental tingkat tinggi. Dalam hal ini Vygotsky menekankan pentingnya komunikasi dan kerjasama antar individu untuk berbagi pengetahuan.

Dengan demikian, dongeng dan komunikasi terkait dengan teori sociocultural, karena bahasa merupakan salah satu alat penunjang kebudayaan. Melalui bahasa kebudayaan di Indonesia 
PEDAGOGIKA

Jurnal IImu Pendidikan

Volume 9 (Nomor 2) 2018

dapat dilestarikan dengan meneruskan

Komunikasi memiliki beberapa

informasi kepada generasi-generasi

berikutnya dan pelestarian budaya

unsur, diantaranya : (1) komunikator

dilakukan melalui proses belajar bukan

pewarisan (Poerwanto, $2008: 89$ ).

\section{Kemampuan Komunikasi}

Komunikasi yang efektif adalah komunikasi yang melahirkan kebersamaan, kesepahaman antara sumber dan penerima. Komunikasi akan efektif jika di dalam proses komunikasi terdapat interkasi antara komunikator dengan komunikan. Dalam hal ini komunikan memberikan umpan balik kepada komunikator baik itu dengan menggunakan bahasa verbal (kata-kata) atau dengan non verbal (tingkah laku).

Komunikasi adalah proses penyampaian pesan berupa informasi dari sumber sebagai komunikator kepada penerima sebagai komunikan melalui media sebagai penyalur. Komunikasi akan terjadi jika terdapat kesamaan pemahaman antara sumber dan penerima. Komunikasi akan efektif jika terjadi interaksi antara sumber dengan penerima. Penerima akan memberikan umpan balik berupa tanggapan dari informasi yang sudah diterima. (Effendy, 2006 :9, Tebba, 2008 :59, Hamidi, 2007:70, Suprapto, 2006 : 5,Hoff, 2005:244).

(communicator, source,sender), (2) Pesan (message), (3) Media (channel, media), (4) Komunikan (communicant, communicate, receiver, recipient), (5) efek (effect, influence). Proses komunikasi akan terjadi jika terdapat unsur-unsur tersebut. Komunikasi berdasarkan prosesnya dibedakan menjadi dua, yaitu komunikasi primer dan komunikasi sekunder (Effendy,2006 : 10).

Komunikasi primer adalah komunikasi dengan proses penyampaian pikiran atau perasaan seseorang kepada orang lain dengan menggunakan lambang atau symbol sebagai media. Symbol yang digunakan dalam komunikasi primer adalah bahasa, isyarat, atau gambar. Komunikasi sekunder adalah komunikasi dengan proses penyampaian pesan oleh seseorang oleh orang lain dengan menggunakan alat atau sarana sebagai media kedua setelah lambang sebagai media pertama. Contoh komunikasi sekunder diantaranya surat, telepon, telegraph, majalah dan lain sebagainya. Media yang banyak digunakan untuk menyampaikan informasi atau pesan dalam proses komunikasi adalah bahasa. Melalui bahasa seseorang lebih mudah menyampaikan ide, informasi atau opini, 
PEDAGOGIKA

Jurnal IImu Pendidikan

Volume 9 (Nomor 2) 2018

baik itu secara konkret maupun abstrak (Scwarzt, 1993 : 34).

Menurut Scott dalam Suprapto, terdapat beberapa hal yang dapat mempengaruhi proses komunikasi, diantaranya : (1) the act, (2) the scene, (3) the agent, (4) the agency, (5) the purpose (Suprapto, 2006:7). The act atau perbuatan adalah perbuatan komunikasi menginginkan penggunaan lambanglambang yang dapat dimengerti secara baik dan hubungan-hubungan yang dilakukan oleh manusia. The scene atau adegan adalah salah satu faktor yang menekankan hubungan dengan lingkungan komunikasi, seperti kegiatan yang dilakukan, simbol yang digunakan, maksud yang disampaikan. The agent atau pelaku, yaitu individu-individu yang mengambil bagian dalam hubungan komunikasi, dalam hal ini sumber dan penerima. The Agency atau perantara, yaitu media yang digunakan dalam proses komunikasi. Terakhir adalah the purpose atau tujuan. Sumber harus memiliki tujuan ketika menyampaikan informasi agar terjadi kesepahaman antara sumber dan penerima informasi.

Kemampuan Komunikasi terdiri dari dua kata yaitu kemampuan dan Komunikasi. Kemampuan adalah kapabilitas seseorang yang baik dari suatu bidang ilmu dan akan berkembang. Hal ini dapat berkembang jika orang tersebut berlatih/ belajar. Latihan mengembangkan kemampuan juga dapat memperkaya pengalaman belajar orang tersebut (Jarolimek, 1989: 32,Fogharty, 1991 : 64, Dean,2005 :42, Adam dan Waskito, 2007 :287).

Berdasarkan pemaparan sebelumnya, Komunikasi adalah proses penyampaian pesan berupa informasi dari sumber sebagai komunikator kepada penerima sebagai komunikan melalui media sebagai penyalur. Komunikasi akan terjadi jika terdapat kesamaan pemahaman antara sumber dan penerima. Komunikasi akan efektif jika terjadi interaksi antara sumber dengan penerima. Penerima akan memberikan umpan balik berupa tanggapan dari informasi yang sudah diterima.

Jadi, kemampuan komunikasi adalah kapabilitas seseorang dalam proses menyampaikan pesan atau informasi dari sumber kepada penerima melalui media bahasa. Kemampuan komunikasi akan berkembang jika orang tersebut berlatih atau belajar. Semakin sering seseorang berlatih komunikasi dengan orang lain maka kemampuan komunikasi orang tersebut akan berkembang. 
PEDAGOGIKA

Jurnal IImu Pendidikan

Volume 9 (Nomor 2) 2018

Hal ini seperti yang dikemukakan oleh Golden dan kawan-kawan dalam Catron dan Allen (Carton dan Allen, 1999 : 255). Dalam Catron dan Allen,Golden dan kawan-kawan mengemukakan bahwa berlatih komunikasi dapat mengembangkan kemampuan komunikasi anak usia dini, karena dengan semakin seringnya anak berkomunikasi maka akan semakin banyak perbendaharaan kata yang anak miliki dan anak akan semakin memahami komunikasi secara bermakna.

\section{Karakteristik}

Perkembangan

Kemampuan Komunikasi Anak Usia 7-

\section{Tahun}

Menurut Santrock, anak usia 7-8 tahun sudah mulai dapat merespon kata yang merupakan bagian dari percakapan sesuai dengan stimulus yang diberikan. Anak sudah memiliki banyak perbendaharaan kata (kurang lebih 50.000 kata) dan mulai mengkategorikan perbendaharaan kata ke dalam kelas kata. Sebagai contoh, anak sudah dapat mengkategorikan kata anjing dengan kucing. Anjing dan kucing masuk dalam kategori hewan peliharaan.

Kemampuan komunikasi anak usia 7-8 tahun memiliki beberapa karakteristik sebagai berikut : (1) anak sudah mampu merespon percakapan sesuai stimulus yang diberikan, (2) anak mulai mengkategorikan perbendaharaan yang dimiliki sesuai kelas kata, (3) mampu berbicara dengan bermakna, (4) mampu menerapkan aturan tata bahasa sejajar dengan orang dewasa, (5) sudah mampu mengungkapkan hal yang akan dan sedang dikerjakan, keberhasilan yang akan dicapai, serta kendala yang akan ditemui, (6) anak sudah dapat menggunakan komunikasi verbal secara interaktif dengan orang dewasa seperti dengan teman sebaya, seperti bercanda atau menggoda (Bredekamp, 1996 : 135, Carton dan Ellen, 1999:255, Jamaris, 2009 : 146) .

c.Dasar Teori Komunikasi

Teori yang mendasari proses komunikasi adalah teori operant conditioning atau pengkondisian operan adalah teori perubahan perilaku yang dicapai sebagai hasil belajar melalui proses penguatan (reinforce) positif atau negatif. Teori ini ditemukan oleh Burrhus Frederic Skinner (Woolfolk, 2007 : 210). Menurut Skinner dalam Woolfolk, perilaku dapat dianalogikan sebagai sebuah sandwich yang memiliki dua pengaruh lingkungan terhadap perilaku. Lapis pertama adalah antesedence (peristiwa yang mendahului perilaku) dan lapis kedua adalah consequences (peristiwa yang mengikuti perilaku). Hubungan dapat ditunjukkan secara sederhana sebagai rangkaian 
PEDAGOGIKA

Jurnal IImu Pendidikan

Volume 9 (Nomor 2) 2018

antecedents-behaviour-consequnces atau

A-B-C. Dalam hal ini perilaku adalah sebuah proses dari consequences yang diberikan perilaku akan menjadi antecedents bagi rangkaian A-B-C berikutnya. Penelitian ini menunjukkan bahwa perilaku operan dapat diubah dengan mengubah anteseden atau konsekuen atau keduanya.

Menurut Crain, hasil penelitian Skinner menghasilkan beberapa prinsipprinsip belajar, diantaranya : reinforcement, punishment, shaping, extinction, serta antecedent dan perubahan perilaku (Crain, 2007 : 279-278). Reinforcement merupakan konsekuen yang menguatkan tingkah laku. Punishment yaitu menghadirkan atau memberikan sebuah situasi yang ingin dihindari untuk menurunkan tingkah laku. Shaping adalah usaha untuk menunjukkan keterampilanketerampilan baru atau perilaku-perilaku baru dengan memberikan penguatan kepada siswa untuk menguasai keterampilan atau perilaku tersebut dengan baik. Extinction adalah mengurangi atau menurunkan tingkah laku dengan menarik reinforcement yang menyebabkan perilaku tersebut terjadi. Antecedent adalah petunjuk perilaku akan memproleh konsekuen positif atau negative. Dua cara yang dapat dilakukan untuk mengontrol anteseden adalah dengan melakukan cueing (memberikan stimulus sebelum tindakan dilakukan) dan prompting (petunjuk tambahan agar dapat melakukan dengan benar).

Proses komunikasi terkait dengan teori operan conditioning. Stimulus pada proses komunikasi adalah informasi yang disampaikan oleh komunikator. Kemudian dari stimulus tersebut akan muncul respons atau tanggapan dari komunikan yang akan memberikan umpan balik sebagai efek dari stimulus.

Beberapa penelitian sebelumnya pernah dilakukan mengenai pengaruh komunikasi dan dongeng terhadap kemampuan bercerita. Seperti yang pernah dilakukan oleh Warren menyimpulkan, bahwa dongeng memberikan pengaruh positif terhadap kemampuan berbahasa siswa. Pada penelitian ini dongeng berguna sebagai pengalaman berbahasa bagi anak untuk meningkatkan kemampuan menyimak, berbicara, membaca, dan menulis (Jurnal, Warren, 2010).

Penelitian lain tentang dongeng yang dapat mengembangkan kemampuan bercerita, pernah dilakukan oleh Sundari. Penelitian ini dilakukan di Sekolah Menengah Pertama di Jember. Penelitian ini menyimpulkan bahwa, melalui metode dongeng

kemampuan 
PEDAGOGIKA

Jurnal Ilmu Pendidikan

Volume 9 (Nomor 2) 2018

bercerita,kemampuan menulis, serta membaca bahasa Inggris siswa kelas VII meningkat dengan baik (Jurnal, Sundari, 2011).

Penelitian mengenai komunikasi pernah dilakukan oleh Hernawati. Penelitian tentang pengembangan kemampuan berbicara melalui komunikasi yang dilakukan pada anak tunarungu menyimpulkan, bahwa melalui komunikasi verbal dengan melakukan percakapan seperti antara ibu dan anak akan mengembangkan kemampuan berbicara anak tunarungu. Hal ini didasarkan pada pemrolehan bahasa anak. semakin banyak anak berlatih berkomunikasi maka anak akan semakin banyak memperoleh kosakata, sehingga kemampuan bicara anak akan semakin berkembang (Jurnal, Hernawati, 2007).

\section{C.METODE PENELITIAN}

Metode Penelitian yang digunakan dalam penelitian ini adalah Penelitian Tindakan kelas atau Classroom Action Research. Acuan yang digunakan dalam penelitian Classroom Action Research adalah "The Action" model kemmis, langkah-langkah tercermin dalam "Refleksi diri " Action Research yaitu "reconnaissance, plan, action, observation, reflection". Seperti gambar berikut ini :

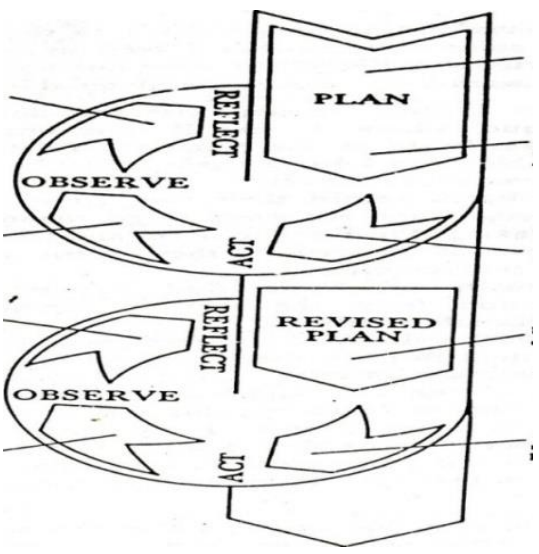

Gambar 1 : The Action Research Kemmis and Taggart

Pelaksanaan penelitian ini dilakukan sebanyak dua siklus. Masingmasing siklus direncanakan dengan pola yang sesuai dengan tahapan setiap siklus yakni perencanaan, tindakan, pengamatan dan refleksi. Adapun tujuan setiap siklus sama yaitu untuk mencapai peningkatan kemampuan komunikasi pada siswa kelas II SD sesuai dengan tahapan kompetensi yang telah ditentukan dari awal.

Proses perencanaan, dirancang kegiatan yang memadukan bermacammacam kegiatan sambil belajar dengan pengembangan kemampuan komunikasi anak. Rancangan kegiatan dilakukan bertahap sesuai dengan tahapan Anak mampu merespon percakapan sesuai stimulus yang diberikan, dapat mengkategorikan perbendaharaan kata yang dimiliki sesuai kelas kata, mampu 
PEDAGOGIKA

Jurnal IImu Pendidikan

Volume 9 (Nomor 2) 2018

mengutarakan ide pendapat dan orang lain memahami maksud yang anak sampaikan, dapat menerapkan aturan tata bahasa sejajar dengan orang dewasa, dapat membuat perencanaan dengan mengungkapkan hal yang akan dan sedang dikerjakan, keberhasilan yang akan dicapai, serta kendala yang akan ditemui, sudah dapat lebih interaktif dengan orang dewasa berkomunikasi seperti dengan teman sebaya . Kemampuan mengajar dilihat dari aktivitas guru dalam menyajikan pembelajaran, instrumen selengkapnya dapat di lihat pada lampiran.

Tindakan dilakukan berdasarkan pada skenario pembelajaran telah dirancang pada tahap pertama. Pada saat proses pelaksanaan tindakan sedang berlangsung, peneliti melakukan pengamatan detail tentang kegiatan pembelajaran. Peneliti mencatat dan merekam permasalahan yang timbul pada saat kegiatan pembelajaran berlangsung. Proses tindakan sekaligus pengamatan ini dilakukan bersamaan. Dengan demikian telah berlangsung empat tahap dalam siklus pertama.

Tahap refleksi dalam penelitian ini adalah mengkaji, melihat dan merenungkan kembali hasil atau dampak dari tindakan yang telah dicatat dalam observasi. Hasilnya dianalisis, di interprestasikan dan disimpulkan bersama peneliti dan guru. Kesimpulan ini merupakan dasar merevisi rencana untuk diterapkan pada tindakan berikutnya. Selain itu digunakan pula catatan jurnal mengajar dan data hasil belajar siswa untuk melihat adanya peningkatan hasil belajar anak dengan menerapkan metode dongeng dalam perbaikan mengajar.

\section{D.HASIL PENELITIAN DAN PEMBAHASAN}

Penelitian dilaksanakan pada siswa kelas II SDIT Alhusna angkatan 2014/2015 yang beralamat di Taman Wisma Asri,Bekasi Utara. Adapun alasan peneliti memilih sekolah ini sebagai tempat penelitian adalah sebagai berikut: Permasalahan komunikasi dialami oleh siswa kelas II SDIT Alhusna. Penelitian tindakan ini membutuhkan kerjasama dan hubungan yang baik dengan guru. Guru SDIT ALhusna sudah mengenal peneliti dan mau di ajak bekerja sama dalam melakukan penelitian. Cara mengajar untuk meningkatkan kemampuan berkomunikasi siswa kelas II SDIT Alhusna masih belum sepenuhnya terlaksana dengan baik, untuk itu perlu perubahan dalam metode dan teknik dalam mengajar. Penelitian ini membantu guru 
PEDAGOGIKA

Jurnal IImu Pendidikan

Volume 9 (Nomor 2) 2018

untuk melakukan perubahan dalam proses pembelajaran.

Penelitian ini dilaksanakan selama 3 bulan, di mulai pada bulan September sampai November 2014. Waktu pelaksanaan kegiatan dilakukan mengikuti waktu kegiatan pembelajaran yang berlangsung secara rutin di dalam kelas mulai hari senin sampai hari sabtu.

Penelitian ini melibatkan guru SDIT Alhusna sebanyak 2 orang dan semua siswa Kelas II SDIT Alhusna sejumlah 22 orang. Guru bertindak sebagai pemberi materi pembelajaran dan siswa kelas II SDIT Alhusna sebagai subjek penelitian.

1. Kegiatan Pra-Penelitian

Sebelum peneliti melakukan kegiatan pertama, peneliti melakukan persiapan-persiapan pra-penelitian sebagai berikut :

a. Mencari dan mengumpulkan informasi atau data anak yang akan menjadi subjek penelitian. Informasi atau data tersebut diperoleh dari hasil observasi langsung terhadap anak-anak yang menjadi subjek dalam konteks pembelajaran. Berdasarkan observasi awal ke sekolah dan informasi dari guru kelas II SDIT Alhusna, dapat diketahui bahwa kemampuan komunikasi anak masih banyak yang belum berkembang dengan baik sesuai dengan tahapan umur siswa.

b. Menentukan waktu pelaksanaan penelitian, yaitu pada bulan September sampai November.

c. Mempersiapkan RPP, media dan alat yang akan digunakan selama penelitian.

d. Mempersiapkan instrumen untuk mengukur kemampuan komunikasi siswa,mengamati kegiatan guru dan aktivitas siswa dalam kegiatan pembelajaran.

\section{Kegiatan Siklus I}

Setelah melakukan persiapanpersiapan pra-penelitian, selanjutnya peneliti melakukan penelitian tindakan yang dimulai dari siklus pertama dengan tahapan sebagai berikut :

Perencanaan

Perencanaan Umum

Perencanaan umum disusun berdasarkan permasalahan penelitian sebagaimana dipapar kan sebelumnya, yakni terkait dengan peningkatan kemampuan komunikasi siswa kelas II SDIT Alhusna Bekasi Utara. Pada tahapan ini peneliti merencanakan waktu pembelajaran dengan menyiapkan RPP rencana pembelajaran, menyiapkan media dan alat peraga, serta membuat instrumen 
PEDAGOGIKA

Jurnal IImu Pendidikan

Volume 9 (Nomor 2) 2018

kemampuan komunikasi anak, telah dilakukan, mendiskusikan dan pengumpulan data, dan evaluasi hasil belajar untuk keseluruhan siklus.

Pada siklus pertama dilakukan lima kali pertemuan masing-masing siklus dilakukan melalui empat tahap yaitu perencanaan, tindakan, pengamatan, dan refleksi. Pada tahap perencanaan peneliti menatar guru tentang aspek yang akan dinilai selama proses pembelajaran yaitu, menceritakan dongeng modern tentang fabel, bercerita tentang isi gambar dengan urut dengan bahasa yang jelas, dan menceritakan kembali cerita secara urut. Kemudian merancang dan menyiapkan RPP, menyediakan media yang dibutuhkan dan mengatur ruangan secara bersamasama. Tahap tindakan atau tahap pelaksanaan yaitu tahap mempraktekan dan melaksanakan RPP sesuai dengan skenario pembelajaran. 1 Tindakan dilakukan selama 5 kali pertemuan. Tahap pengamatan, dilakukan oleh peneliti dengan mencatat, mendokumentasikan dan mengamati proses berlangsungnya kegiatan pembelajaran. Tahap akhir, dilakukan dengan membuat refleksi dan kesimpulan yang telah dilakukan. Tahap ini dilakukan setelah tindakan dilakukan sebanyak 5 kali pertemuan. Tahap ini, peneliti dan guru merefleksi tindakan yang

${ }^{1} \mathrm{SKH}$ selengkapnya dapat di lihat pada lampiran melakukan perubahan dalam perencanaan selanjutnya, dan melakukan analisis keberhasilan program pada siklus pertama.

\section{2). Perencanaan Khusus}

Perencanaan khusus penelitian ini dirumuskan sesuai dengan siklus dan memuat secara komprehensif perencanaan masing-masing siklus. Pada perencanaan khusus penelitian ini, peneliti bersama kolaborator menyiapkan format catatan lapangan untuk melihat hasil pada setiap tindakan, menentukan indikator keberhasilan yang digunakan untuk mengetahuii peningkatkan kemampuan komunikasi siswa kelas II SDIT Alhusna.

Pelaksanaan

Setelah menyiapkan peralatan dan tempat, maka peneliti dan kolaborator melalui pelaksanaan sesuai program yang telah dirancang. Program tindakan siklus pertama terdiri lima kali pertemuan yang disesuaikan dengan waktu belajar yang dijadwalkan. Selain itu di siklus 1 siswa mendengarkan dongeng tradisional. Dongeng diberikan secara satu arah. Siswa hanya mendengarkan cerita setelah itu dilakukan review untuk menceritakan kembali isi dongeng.

Pengamatan

Pedagogika.fup@ung.ac.id P-ISSN : 2086-4469 E-ISSN : 2716-0580| 254 
PEDAGOGIKA

Jurnal IImu Pendidikan

Volume 9 (Nomor 2) 2018

Peneliti bersama kolaborator mengamati tindakan yang dilakukan oleh siswa untuk kemudian dicatat dalam catatan lapangan. Objek yang diamati adalah kemampuan komunikasi siswa. Laporan hasil observasi digunakan sebagai bahan pertimbangan untuk membuat program perbaikan tindakan selanjutnya. Selain menggunakan catatan lapangan, peneliti juga menggunakan alat bantu dokumentasi berupa kamera dan video yang akan menunjukkan kemampuan bicara yang dilakukan anak. Dengan demikian, akan diperoleh bukti konkret selama kegiatan berlangsung.

\section{Refleksi}

Refleksi merupakan upaya evaluasi yang dilakukan bersama kolaborator. Maksud pelaksanaan refleksi ini adalah untuk menganalisa ketercapaian proses pemberian tindakan maupun untuk menganalisis faktor penyebab tidak tercapainya tindakan. Peneliti dan kolaborator menganalisis tingkat ketercapaian dan faktor penghambat yang diperoleh dari catatan lapangan. Hasil dari refleksi ini digunakan untuk menentukan tindakan pada siklus pertama (1) yang akan diperbaiki dalam pelaksanaan siklus Kedua (2).
Kegiatan Siklus Kedua (2)

Setelah melakukan tahapantahapan penelitian tindakan pada siklus I, peneliti melanjutkan penelitian tindakan pada siklus II dengan tahapan sebagai berikut.

\section{Perencanaan}

Dari hasil siklus pertama, peneliti menyusun perencanaan untuk pelaksanaan penelitian tindakan siklus II. Pada siklus kedua dilakukan sebanyak Lima kali pertemuan, melalui 4 empat tahap yang sama dengan siklus Pertama namun perencanaan yang dilakukan dengan mengacu dengan analisis refleksi dari siklus pertama dan pelaksanaan proses pembelajaran yang melibatkan aktivitas siswa belajar demikian seterusnya sampai akhir siklus kedua. Jika hasil tes kemampuan siswa pada siklus kedua telah terlihat peningkatan pada kemampuan komunikasi siswa, maka penelitian dihentikan dengan asumsi bahwa program tersebut sudah dapat diterapkan dalam kegiatan pembelajaran untuk siswa kelas II SD.

Pelaksanaan

Setelah menyiapkan peralatan dan tempat, peneliti dan kolaborator memulai pelaksaan sesuai program yang telah 
PEDAGOGIKA

Jurnal IImu Pendidikan

Volume 9 (Nomor 2) 2018

dirancang. Program tindakan siklus II terdiri atas beberapa pertemuan yang disesuaikan dengan waktu belajar yang dijadwalkan sekolah.

Pengamatan

Pengamatan dilakukan dengan instrumen pengamatan yang telah diperbaharui sesuai dengan tindakan yang telah disepakati oleh peneliti dan kolaborator

Dari hasil tindakan dari siklus pertama (1) dan kedua (2) terjadi peningkatan. Peningkatan tersebut terlihat dari perbedaan rata-rata skor aktivitas anak pada siklus 1 dan siklus 2. Adapun peningkatan tersebut pada siklus 1 memperoleh skor 63 pada kriteria cukup aktif dan siklus kedua skornya meningkat menjadi 97 termasuk kriteria sangat aktif selain itu harapan lain adalah program kegiatan berdongeng dapat diterapkan dalam kegiatan pembelajaran untuk siswa kelas II SD dalam meningkatkan kemampuan komunikasi siswa.

\section{E.KESIMPULAN}

Dari hasil tindakan dari siklus pertama (1) dan kedua (2) dapat disimpulkan bahwa terjadi peningkatan. Peningkatan tersebut terlihat dari perbedaan rata-rata skor aktivitas anak pada siklus 1 dan siklus 2. Adapun peningkatan tersebut pada siklus 1 memperoleh skor 63 pada kriteria cukup aktif dan siklus kedua skornya meningkat menjadi 97 termasuk kriteria sangat aktif selain itu harapan lain adalah program kegiatan berdongeng dapat diterapkan dalam kegiatan pembelajaran untuk siswa kelas II SD dalam meningkatkan kemampuan komunikasi siswa.

Beberapa saran sebagai masukan dan tindak lanjut berkaitan dengan hasil Penetian ini sehingga dapat menambah pengetahuan dan wawasan mengenai peningkatan kemampuan komunikasi siswa kelas II SD melalui metode dongeng, sehingga penelitian ini dapat memberikan nilai kontribusi positif terhadap dunia pendidikan. Diantaranya : 1) Bagi Anak, Untuk meningkatkan kemampuan komunikasi, dan keterampilan menggunakan bahasa indonesia yang baik dan benar melalui metode dongeng sehingga anak terlibat aktif serta aspek bahasanya dapat berkembang secara optimal sesuai dengan taraf perkembangan usiannya. 2) Bagi Guru, Sebagai masukan bagi para pendidik khususnya guru Kelas II Sekolah Dasar tentang variasi metode pembelajaran dalam mengembangkan kemampuan komunikasi yaitu melalui dongeng. 3) Bagi Orang tua, Memberi 
PEDAGOGIKA

Jurnal IImu Pendidikan

Volume 9 (Nomor 2) 2018

informasi bagi para orang tua tentang pentingnya perkembangan kemampuan berkomunikasi dan dongeng pada anak usia dini. 4) Bagi Peneliti, Di harapkan peneliti memperoleh informasi terpercaya dan dapat dijadikan bekal untuk meningkatkan dan mengembangkan kreativitas, inovasi, keterampilan dalam menyusun, menyajikan pembelajaran yang menarik.

\section{REFERENSI}

Ahira, Anne. "Pengaruh Cerita Dongeng Terhadap Mental dan Prestasi Sebuah Bangsa" Artikel (www.senimusikdananak.blogspo t.com, diunduh pada 3 Desember 2010)

Al-Qudsy,Muhaimin dan NurHidayah, Ulfah, 2010.Mendidik anak Lewat Dongeng, Yogyakarta : Madania.

Astuti, Marfuah Puji,“ Dongeng aktifkan Simpul Syaraf" Jurnal (http://tanayasho.multiply.com/jo urnal?page start:20 diunduh pada 27 april 2011)

Bakhtiar, Amsal. 2008.Filsafat Ilmu Jakarta : PT. Raja Grafindo Persada,
Beverly, Eisel. 1991.Managing The Whole Language Classroom ,Creative Teaching Press.

Bredekamp, Sue, Developmentally Appropriate Practice in Early Childhood Programs Serving Children From Birt Trhough Age 8 (Washington : National Association for The Education of Young Children,/'op 1992)

Carton, Carol E dan Allen, Jan. 1999.Early Childhood Curriculum a Creative-Play Model USA : Prentice-Hall Inc.

Cendana, Rawittri, "Pendekatan Pembelajaran Apresiasi Dongeng dengan Media Visual Manipulatif Boneka"Jurnal Pendidikan (Surakarta : Universitas Muhammadiyah Surakarta, 2010), h. 4

Crain, William, 2007.Teori Perkembangan Konsep dan Aplikasi .Yogyakarta : Pustaka Pelajar.

Dardjowidjojo, Soenjono, 2010,Psikolinguistik Pengantar Pemahaman Bahasa Manusia (Jakarta ; Yayasan Obor Indonesia.

Dariyo, Agoes. 2007Psikologi Perkembangan ,Bandung : PT. Refika Aditama,. 
Dean, Joan. 2005.The Effective Primary School Classroom,London : Routledge Falmer.

Effendy, Ojong Uchjana, 2006,Ilmu Komunikasi teori dan praktek,(Bandung : PT. Remaja Rosdakarya.

Einon, Dorothy. 2006.Learning Early, Jakarta : Dian Rakyat.

Eko Muchayat, "Teknologi, Budaya Baca dan Dongeng" Jurnal Radar Banten

(http://nuliswae.multiply.com/jour nal/item/12 diunduh pada 27 April 2011)

Eliason dan Jenkins, 2008.A Practical Guide to Early Childhood Curriculum Ohio : Pearson.

Fogharty, Robin, 1991. The Mindful School:How to Integrate The Curricula,Illinois : Iriskylight.

H. Baharrudin dan Wahyuni, Esa Nur. 2009.Teori Belajar dan Pembelajaran, Yogyakarta : ArRuzz Media.

Hamidi, 2007.Metode Penelitian dan Teori Komunikasi,Malang : Universitas Muhammadiyah Malang.

Hawadi, Reni Akbar, 2001, Psikologi Perkembangan Anak, Jakarta : PT. Grasindo.
Hernawati, Tati "Pengembangan Kemampuan Berbahasa dan Berbicara Anak Tunarungu" Jurnal (Jassi_Anakku Volume 7 Nomor 1, Juni 2007)

Hoff, Erika. 2005.Language Development ,United States of America : Thomson Learning.

Huck, Charlotte S. dkk, 1987.Children Literature in the Elementary School ,USA : Holt, Rinehart and Winston Inc.

Jalongo, Mary Renck. 2007. Early Childhood Language Arts, USA : Pearson.

Jamaris, Martini, 2009,Kesulitan Belajar, Perspektif, Assesmen, dan Penganggulangannya Jakarta : Yayasan Penamas Murni.

Jarolimek, John. 1986.Social Studies in Elementary Education.Macmillan Publishing Company.

Kurikulum Tingkat Satuan Pelajaran SDMI, Jakarta : Departemen Pendidikan Nasional, 2006.

Kusmiadi, Ade. "Strategi Pembelajaran PAUD melalui Metode Dongeng bagi Pendidik PAUD” Jurnal Ilmiah Visi PTK$P N F$, Jurnal.pdii.lipi.go.id/admin/j urnal/3208198203.pdf diunduh pada 27 April 2011. 
Mulyadi, Seto, “Ayo Mendongeng!’Nakita No. 604/TH.XII, 25-31 Oktober 2010.

Nugroho, Hadi Setyo, "Pengaruh Komunikasi, Pengelolaan Kelas, dan Proses Pembelajaran Terhadap Prestasi Belajar Matematika" Jurnal Pendidikan (Hadisetyo.wordpress.com, 19 November 2009) diunduh pada 3 November 2010

Nur'ain, Farida, 2007. Pedoman Mendongeng untuk Orang tua dan Pendidik, Surakarta:Afra.

Nurani, Yuliani, 2009.Konsep Dasar Pendidikan Anak Usia Dini .Jakarta : PT. Indeks.

Peraturan Menteri Pendidikan Nasional Nomor 23 Tahun 2006

Priyono, Kusumo. 2006.Terampil Mendongeng, Jakarta : Grasindo.

Raines, Shierly C.dan Canady, Robert J.1990.The Whole Language Kindergarten ,New York : Teacers College Press.

Ralibi, Imam Maliki, 2008, Fun Teaching ,Cikarang : Duha Khazanah.

Santrock, John W. 2009.Psikologi Pendidikan (Educational Psychology) Jakarta : Salemba Humanika.
Sawyer, Walter E. dan Comer, Diana E. 1996,Growing Up with Literature,Delmar Publishers.

Scwartz, Judith I. 1993.Encouraging Early Literacy .Porthsmouth, New Hempshire.

Soedjatmiko, et all, Masalah Sosial Budaya 2000, (Yogyakarta : Tiara Wacana, 2000), h.66

Sundari, Siti, "Meningkatkan Kualitas Pembelajaran Menyimak, Membaca, dan Menulis Bahasa Inggris di SMP 1 Jember" Jurnal (Jurnal.pdii.lipi.go.id diunduh pada tanggal 17 Maret 2011)

Suprapto, Tommy. 2006,Pengantar Teori Komunikasi ,Yogyakarta : Media Pressindo.

Tebba, Sudirman, 2008.Filsafat dan Etika Komunikasi ,Tangerang : Pustaka Irvan.

Undang-undang Sistem Pendidikan Nasional (Jakarta : Absolute, 2003), h.9 dan 26

Warren, "Once Upon a time: The learning experiences of Novice English second language students with fairy tale", Tesis (home.moravian.edu/public/educ/ eddept $/ \mathrm{mEd} /$ thesis.htm diunduh pada 6 Desember 2010) 
PEDAGOGIKA

Jurnal Ilmu Pendidikan

Volume 9 (Nomor 2) 2018

Woolfolk, Anita, 2007. Educational Sastra Indonesia di Kelas Rendah psychology ,Pearson Education ,Jakarta : Departemen Pendidikan Inc., dan Kebudayaan,

Zuchdi,Darmiyati dan Budiasih, 1997.Pendidikan Bahasa dan 